\title{
Unlock the volume: towards a politics of capacity
}

Kimberley Peters and Jennifer Turner (accepted in Antipode, March 2018)

\begin{abstract}
In recent years 'volume' has become a key analytic idea, and tool, for re-imagining and making sense of historical and contemporary socio-cultural and geopolitical phenomena. This paper argues that this important work could be pushed in new directions by thinking seriously of how volume might otherwise be interpreted spatially, as capacity. Accordingly, in this paper, we address what we call a 'politics of capacity'. To do so, we draw specifically on debates in carceral geography and, in particular, the pressures on the prison system to illustrate our argument. Drawing on notions of 'operational capacities' and 'capacity building' in the prison setting, we outline a manifesto for volumetric thinking that moves beyond expressions of power that cut through height, depth and angles, to an understanding how power is conveyed through maximum and minimum capacities; density and mass; and capacity building techniques.
\end{abstract}

Key words: Volume, Capacity, Carceral, Prison, Politics

\section{Introduction}

This paper outlines an agenda for taking seriously a 'politics of capacity'. Although capacity has a long history of usage in population studies (Sayre 2008), it has been absent from a turn towards 'volume' as a key analytic idea and tool for re-imagining and making sense of historical and contemporary socio-cultural and geopolitical phenomena. As Elden (2013), Graham (2004) and others (Bridge 2013; Gordillo 2015; Squire 2016; Steinberg and Peters 2015) have shown, power is not expressed, or directed, across two-dimensional, areal, planes 
of space. Power is distributed (and resisted) through height, depth and angles; in other words, through volume. This paper argues that this important work could be pushed in new directions through an attention to capacity in volumetric thinking. Rather than conceiving of volume through engaging with questions of height, depth and angles and the spaces this opens-up for the expression and resistance of power, we might also think of other ways of interpreting volumetric politics - notably through thinking explicitly of volume as capacity; the amount of ' $X$ ' that fills a given volume.

In what follows we begin a project that moves towards a politics of capacity drawing firstly on recent debates that have introduced 'volume' into geographic parlance, before homing in specifically on the literature in 'carceral geography' (see Moran 2015; Turner 2016), and the pressures on the prison system to provide a timely and pertinent example to illustrate our argument. The paper therefore builds not only on scholarship concerned with power, territory and volume, but also that which is orientated towards understanding carceral life past and present (see Moran et al. 2013; Moran 2015; Turner 2016). Indeed, as we have argued elsewhere (Authors 2015; 2016), carceral geographies can lend much to debates concerning the geopolitics of height and depth because in such spaces dominating power is not only projected horizontally but through aerial, panopticon surveillance and physical walls and barriers; and practices of resistance occur through escape plans that involve underground tunnelling and rooftop protests (Authors 2016).

Drawing on debates concerning capacity in the context of UK and international prison estates, the paper to follow is split into four parts. We start by expanding upon this introduction, reviewing work which attends to a politics of volume, identifying the capacity to expand this research in fresh directions. We then consider how an exploration of carceral sites (prisons, detention centres, and so on) provides a useful case study for examining a politics of capacity. We next turn to an explicit discussion of capacity in the context of the 
prison; examining first the politics surrounding physical or material capacity in terms of quotas and maximum 'operational capacities' as they are expressed in light of geometric measures of available space in prisons estates. We then consider non-geometric (or Euclidean) conceptualisations of volume, raising questions in respect of resource capacity and capacity building through prison regimes as set out in current prison practices and policy. We conclude by taking the central tenets of our argument developed through the example of the contemporary prison, suggesting further ways that a politics of capacity might be usefully taken forwards.

Whilst a focus on capacity as the physical and social dimensions in which life can be lived may be deemed unfashionable, where Euclidean and geometric notions of space as a container have been all but dispelled in the discipline (Latour 2015; Murdoch 1998; Marston et al. 2005) and where demographic understandings of 'carrying capacity' have been productively challenged (Price 1999; Seidl and Tisdell 1999), in this paper we argue that critically thinking through the lens of capacity is now - more than ever - both timely and relevant as the term is increasingly utilised for political work.

\section{From volume to capacity}

In a trio of highly anticipated books - the Spheres trilogy - the German philosopher Peter Sloterdijk paints a view of space that is characterised by volume $(2012 ; 2014 ; 2016)$. From the intimate, micro-scale of human experience (named 'bubbles'); and the orbs that have characterised western understandings of the 'globe'; to foam (a notion of interlocking and connected spheres), Sloterdijk alerts us to the dimensions of space that envelope experience and shape modern politics. Indeed, on the one hand, Sloterdijk's assertions insist upon a revisioning of our 'embodied' 'earthly' engagements (as Bridge states 2013: 55). For Sloterdijk, life is realised to be within (atmospheric) spheres of space, not within flat, areal 
dimensions. In other words, experience is not played-out on surfaces (as traditional geographic and cartographic thinking would have us believe). The world is spherical in respect of our inhabitation. As Sloterdijk himself states, the world is 'formatted' through our lively and dynamic engagements with the full extents of space which surround us spherically (2009: 232). On the other hand, the work of Sloterdijk is, at present, gaining currency as scholars seek to make sense of the multiple dimensions through which regimes of territory, governance and control are practiced, and resistances, transgressions and deviances are performed (see, for example, Authors 2016). In other words, a theory of spheres or of volume urges us to pay attention to the 'fullness' of space in which politics emerges and functions.

Indeed, in his seminal paper of 2013, Elden asked a fundamental question for scholars of territory: '[h]ow does thinking about volume - height and depth instead of surfaces, three dimensions instead of areas - change how we think about the politics of space? (2013: 35). Elden, drawing on, and extending Weizman's discussion of conflicts in Gaza (2003), demonstrates how power operates via and is projected through the very volumes of space. Politics is not only played-out across flat surfaces. Underground bunkers, aerial offensives, bordering walls that extend vertically, and trenches that are dug downwards, are the volumetric dimensions through which power is asserted and resisted. However, we contend that work on volume - which has expanded substantially, demonstrating how cities, sea spaces, and the air might be better understood through volumetric (or as Steinberg and Peters [2015] put it, 'voluminous') thinking - might be enriched further by deepening our conceptualisation of the term itself. On the one hand, Elden himself has extended this project urging us to consider a politics of terrain; the very 'matter' of territory (2014). How, he asks, does the geophysical nature of territory shape its politics? (See also Adey 2010; Gordillo 2014; Squire 2015; Steinberg and Peters 2015). How, he questions, do bodily relations with 
terrains of water, mud, gravel, ice, snow, alter political engagements? (See also Peters et al. 2018).

Our intention for this paper is to move discussions in a different direction. Volume, as a term, holds particular resonances (see Bridge 2013; Elden 2013; Graham and Hewitt 2013; Weizman 2003). Capacity, as we will show, holds other political meanings, affordances and agencies. On the one hand, capacity can be understood - very simply - as the maximum volume of ' $\mathrm{X}$ ' (people, objects and so on) that can be contained within a particular, physical, bounded space. This chimes with understandings of 'carrying capacities', developed from the work of Thomas Malthus and employed by ecologists and, in geography, population scholars (Seidl and Tisdell 1999). Here capacity has referred to the maximum limits humans can place on natural resources. On the other hand, capacity, as 'filled' volume, is more complex where calculations of volume are not just determined on areal (2D) or cubed (3D) dimensions of space but also available resources to sustain the volume (whatever that volume might be) that is held within. Here calculations of volume may depend on questions of density and mass, again in relation to the subjects and objects held 'within' the given area (Couclelis 2015: 31).

The employment of capacity in demographic studies (in respect of arguments of overpopulation), has been used to make political stakes and claims (see Seidl and Tisdell 1999, 399), especially where there is a policy shift to limit expansion and strengthen borders - be it at national or more local levels; in the context of the state or state apparatus such as detention/holding centres, prisons, and so on. As Seidl and Tisdell note (1999, 407), 'authors discussing social carrying capacity admit the influence of institutional and cultural settings upon it. So, decisions about social carrying capacity are normative or political ones'. As such, whilst capacity, as we describe it, links to a Euclidean understanding of space as absolute, geometric and calculable, we argue that conversations regarding capacity are necessary given the current purchase of the term in political discourse and action (see also, Epilogue). It is 
necessary to unpick how capacity is used to do political work in order to continue to expose, question and critique how Euclidean spatial understandings are put to work in everyday settings, so as to ultimately challenge them. In the sections to follow we seek to 'unlock' capacity as an analytic device exploring how it has been used in prison politics and policy. To do this, we first introduce the sub-field of 'carceral geography' (Moran 2015; Moran et al. 2017) and its usefulness for examining a politics of capacity.

\section{Carceral capacities}

In recent years geographers have increasingly turned their attention to spaces of captivity, holding, detention, quarantine and imprisonment (see Conlon 2011; Loyd et al. 2013; Martin and Mitchelson 2009; Moran 2015; Moran et al. 2017; Turner 2016). Such studies have not only pushed geographers into new empirical territories, but have likewise enlivened geography with fresh theoretical advances that have been made possible by thinking spatially, through carceral space (see Gill 2009; Moran 2015; Mountz 2011; Turner 2016). For Dominique Moran, carceral geography might be defined by three lines of investigation that fold together studies of incarceration with an examination of their implicit geographies (2015: 2). The first characteristic of 'carceral' geography is an interest in what constitutes the 'nature' of a space of incarceration and the experiences that occur within them. The second feature relates to 'spatial geographies of carceral systems' (in other words the orientations made possible within prison sites, such as the specific time-space routines, mobilities within and between carceral institutions, and the border crossings that typify carceral life). The third enquiry is the relationship between forms of carceral spatiality and the punitive state. Together, these lines of investigation have alerted scholars within geography of the importance of carceral sites as very particular spaces for advancing geographical thinking around themes of place-making and home-making (Turner 2013); emotion and space (Crewe 
2014); bordering (see Pickering 2014; Pickering and Weber 2006; Turner 2016); mobility (Conlon 2011; Gill 2009; Authors 2015; 2016); time-space regimes (Moran 2012a; 2012b); and the role of state power in defining practices of incarceration, and in the design of carceral spaces (Martin and Mitchelson 2009; Moran and Jewkes 2015; Moran et al. 2016a; 2016b).

Given the capacity for carceral studies to help us think anew geographically we find it to be fruitful ground for advancing debates concerning territorial power and the expression of volume, especially given the importance of matters of 'volume' to operation of carceral spaces. Indeed, volume is a central yet understated aspect of carceral space even in its most banal and everyday form. For instance, the Panopticon, a type of institutional building designed by English philosopher and social theorist Jeremy Bentham in the late-eighteenth century, has become an iconic emblem of prison space, and one which relies on power expressed through volume. The design consists of a circular structure with an inspection house tower at its centre, from which the managers/staff of the institution can watch or observe (-opticon) all (pan-) the inmates, who are stationed around the perimeter. Inmates, unable to tell whether they are being watched, self-regulate their behaviour in the belief that they are being observed - both by other inmates and by guards in the central inspection tower (See Bozovic 1995). Whilst the Panopticon prison design relies on the self-regulation of the individual across the horizontal spread of the building, it is the vertical omni-presence of the guard at raised height in the tower, and the radial design of the estate, that also enables biopolitical power to be expressed. Expressions of power in the prison then, cut through the horizontal and vertical. Specifically, power is conveyed through volume.

And there are further examples of how volume has been harnessed in carceral settings, in particular for the expression of dominating power, or what has traditionally been understood as power as the 'capacity to act' (Sharp et al. 2000: 5, emphasis added). For example, in medieval times, casting individuals downward to underground cells and 
dungeons was associated with the subjugation of wrong-doers (Turner 2016: 65). Indeed, most early-modern prisons featured an oubliette (from French, literally meaning 'forgotten place'); a deep hole, dug below the prison floor with only one escape route - a trap door in the ceiling. This example of confining prisoners below the earth without the comfort and warmth of natural light was a mark of domination over those individuals through the use of the very volumes of space available.

Yet volume has also been harnessed for exercising resistance. Various moments in prison history reveal occasions where inmates have been able to 'rise upward' through the prison architecture. Rooftop protests, for example, have become a fierce symbol of defiance within the penal setting, with perhaps the most significant being the UK Strangeways riots of 1990. Prison escapes and the presence of contraband into penal settings have also relied on utilising volume. One famous example is the 'Great Escape' of Roger Bushell and 75 others from the Stalag Luft III prison via subterranean tunnels during World War Two (Carroll 2010). Other prisoners travelled upwards. Alfred George Hinds escaped from Nottingham Prison in 1955 over a 20-foot prison wall (Halliday 2014). Most spectacularly, in 1987, John Kendall and Sydney Draper escaped from HMP Gartree when a helicopter landed in the exercise yard. There have been 33 helicopter prison escapes recorded worldwide (Milmo 2010). The notion of the aerial has also made an impact in the presence of contraband in prison spaces. Many items are simply thrown up and over prison walls and fences to be collected by those waiting on the other side. However, advances in technology have also witnessed some more inventive transgressions. In March 2014, a man was arrested for allegedly trying to smuggle drugs into a Melbourne prison using an unmanned drone (Evershed 2014).

Finally, volumes of space are employed in relation to particular prison regimes and individual inmate categorisations. For example, in some prisons, inmates sleep in double or 
triple bunk beds. The hierarchical relationships and territorial contestations that this living situation manifests can have major implications on individuals' ability to afford themselves privacy and avoid confrontational circumstances. Additionally, prisoners may be located on specific 'landings' within the prison depending on their status (in the UK, according to the Incentives and Earned Privileges Scheme (IEP)). Prisoners on enhanced status may occupy cells in higher tiers of the prison owing to their good behaviour. Access to these areas would be restricted for non-enhanced prisoners, confining them to the lower levels of the wing. Similarly, although contrastingly, in some cases, sex offenders have been housed in the top levels of prison, ensuring that they will not interact with the general population due to the risk of potential aggravation by the nature of their crimes (Wener 2012).

As is evident then, there is much to discuss, examine and interrogate in respect of volume in the prison setting (see the Authors 2015; 2016). Accordingly, 'carceral' landscapes provide useful ground for pushing debates concerning height, depth and volume one stage further, in particular in thinking of volume in terms of capacity. Indeed, with volumetric understandings of space currently shaping approaches to studying territory (Elden 2013; Weizman 2003), mobilities (Adey 2010; Adey et al. 2011), and urban space (Graham 2004; 2011; Graham and Hewitt 2013) carceral geography can lend much to the discussion. However, whilst a carceral lens offers much potential for spatial thinking more broadly, the sub-field itself could also be enriched through fully volumising accounts of incarcerated life. Although volume seems to be an intrinsic reality of prison settings, as the sections to follow illustrate, understandings of prison space remain flat. We next turn to the ways in which thinking through 'capacity' can produce new ways of understanding the workings of prison(s), before tentatively drawing out how these examples produce wider ramifications for working with 'volume as capacity' in geography more widely. 


\section{Prison Space I: 'Operational capacities'}

To demonstrate the importance of unpicking capacity as a concept with theoretical and practical relevance for studies of carceral space (and geography more broadly) we must first explore the terms 'volume' and 'capacity' in more depth. Volume can be understood as an intrinsically mathematical configuration - the calculative space that a given shape (or object) occupies. Considering the prison, its volume might be thought of as the sealed, quantifiable space of the three-dimensional boundaries it displays. Put more simply, the volume of a prison estate (if the prison is taken to be a neatly bordered space without leakages or spillages) would be the sum of the space within the set parameter walls (and ceilings). Applied at the scale of the nation-state, volume in physical terms would relate to horizontal area (or length) within the territorial boundary, multiplied by the height and width. A volume then can also be thought of as space contained within set boundaries, which make the calculation of such volume possible. Although it is widely acknowledged that prisons are not sealed, geometric spaces (in line with relational and networked concepts of space, see Turner 2016), as we will show, it is often treated as such to convey a rhetoric of control (and to control) in policy formulation and political discourse. However, the useable volume of space within any measurable border (such as the prison boundary) can vary. This is known as capacity. Every volume of space has a capacity - the maximum amount of ' $\mathrm{X}$ ' a given container can hold. A volume of space (shape or object) can be under or over capacity depending on how much it is 'filled'. A volume of prison space may be determined by the percentage of its capacity - for example in terms of numbers of bodies - and whether it is 'full' or 'empty'. In conjunction with capacity, volumes always have density, which refers to the mass per unit of the volume. Returning to the prison, a volume may be filled more densely with the allocation of more bodies per unit of volume (in other words, per cell) - in relation to the shape and space available. Yet capacity as 'filled' volume also depends not just 
on the space itself, where calculations of volume are determined also on the available resources to sustain the volume (whatever that volume might be) that is held within.

Such understandings of volume position it within a Euclidean framing. Drawing on the mathematic work of Euclid, such an approach takes space to be something geometric - a measurable plane or container on and in which social and physical activity occurs (Couclelis 2015: 31). In Euclidean understandings, space is taken as absolute. This means that space is a pre-existing, pre-determined two or three-dimensional area (or volume) within which we can examine the spatial distribution and organisation of social and physical objects. Although such ways of thinking spatially have fallen out of favour with an appreciation of the interconnectedness of space (Massey 2004); the relations between space (Murdoch 1998); the networks that are formed and forged between actors (Latour 2005); and space as assembled of disparate parts (Anderson and McFarlane 2011), geometric configurations of space persist to underscore and rationalise political decision-making and the formulation of policy. This is particularly the case, as we show, when it comes to designing and managing prison space, and representing such spaces in the public imaginary.

Indeed, dimensions of physical, geometric space are key considerations of both prison designers, operations managers and those organisations who are concerned with the wider ramifications of confined living (such as the United Nations (UN) and the Red Cross). For example, there are minimum physical space requirements set out for prisoners. Based on these minimum requirements it is possible to claim a prison as 'under' or 'over' capacity based on the number or volume of bodies occupying the space. However, minimum requirements are not standardised (in the UK, Europe, or indeed globally), and have been subject to change over time. As such, the politics of capacity differs temporally and spatially. An example illustrates this point. 
On the broadest level, the International Committee of the Red Cross (ICRC) states that available space per prisoner should be no less than $5.4 \mathrm{~m}^{2}$ in single cell accommodation and $3.4 \mathrm{~m}^{2}$ in shared or dormitory accommodation as a 'international' standard (2012: 32-33). Interestingly - and exemplifying our point regarding the need to 'volumise' studies of the carceral - these measurements are squared and refer to areal 2D 'amounts' of space, rather than cubed, 3D space. These measurements lack height. Nonetheless, they provide a geometric, mathematical figure that is used to determine (albeit it incorrectly) the maximum capacity, in light of the recommended minimum space need 'for a prisoner to sleep undisturbed, store personal property and move around' (ICRC 2012: 32). Although ICRC requirements should typically apply worldwide, the Red Cross standards can only function as 'recommendations' and there are some stark variations in their application throughout prison estates internationally. The American Correctional Association's standards for minimum space are for $3.25 \mathrm{~m}^{2}$ per person in single cell accommodation, and $2.32 \mathrm{~m}^{2}$ for multiple cell occupancy (see Table 1). Cells in some jurisdictions vary according to the gender housed within them (such as greater space requirements for women in Iceland, Poland and Slovenia) or differentiated space requirements between adults and juveniles (as is the case in Hungary and Latvia) (see Walmsley 1997). Moreover, the European Prison Rules (EPR), which outline regulatory recommendations for prisons in in the EU, do not specify minimum space requirements at all. However, the Commentary on the EPR refers to the European Committee for the Prevention of Torture (CPT), which outlines 'an absolute minimum requirement of 4 square metres for prisoners in shared accommodation and 6 square metres in a single cell' (van Zyl Smit and Snacken 2009: 132). Additionally, although not specifically prescribed, the CPT deems 9-10 $\mathrm{m}^{2}$ to be a 'desirable' size (Council of Europe 2005: comments on rule 15). 
<Insert Table 1: Space available per prison in selected regions/countries according to available published guidelines (figures compiled from ICRC 2012 and MoJ 2012) about here>

In reviewing the current minimum physical amount of space specified in policy guidelines from the international, regional, to national level we can see how prison design and prison space is treated in Euclidean terms, with allocated geometric dimensions indicative of a minimum requirement per inmate. In turn, these minimum requirements feed into the maximum capacity that any given prison can hold. These measurements are, of course, problematic. Prisoners - like us all - do not live in planar, areal space, but in a spherical world that has height (see Sloterdijk 2014). Although such measurements are used to refer to the overall living space of those incarcerated, they are flat measurements. Accordingly, prisons and reform agencies must, we would argue, use cubed measurements to properly account for minimum spatial requirements. This is all the more important when we consider that there are prisons that may meet 'squared' requirements but where prisoners cannot fully stand up, properly sleep or move around in their cell because of limited overall volume.

However, this example demonstrates how, in the context of the prison, discrete pockets of space are mathematically calculated to contain those within (ideally) humane, but no less constricting ways. Euclidean mathematics is essential to the design of prison space and its organisation in terms of the number of inmates that may 'fill' such a space. So, whilst much literature pertaining to prison boundaries explores them as compromised, leaky, with an unclear line between inside and outside, as Turner writes: 'the prison boundary (still) has to be effective' $(2016,52)$. In policy and practice then, Euclidean dimensions remain essential to the daily operation of prison space. 
Indeed, the language of a minimum volume of space per prisoner in policy directives and recommendations also alerts us to the matter of capacity. In other words, if we are to follow the ICRC requirements, that a single prisoner should be held in a space no less than $5.4 \mathrm{~m}^{2}$, then the maximum capacity for a $5.4 \mathrm{~m}^{2}$ single cell is one person. With one person in a cell of that size, the cell is deemed to be 'full to capacity'. As such, thinking of prison as a geometric shape with a volume (and a volume that relates to its capacity and density) can assist us in making sense of prison management and policy in terms of, primarily, issues surrounding prison capacity. Indeed, whilst policy may direct that a cell sized $5.4 \mathrm{~m}^{2}$ should only hold one prisoner, more than one person can and would fit in a space of that size. Accordingly, prisons calculate the usage of their space and 'maximum capacities' not merely on problematic, flat mathematical dimensions but the extent of their resources and nature of their operations.

In the UK (and some countries elsewhere) prisons have 'operational capacities' relating to the maximum amount a volume of prison space may be filled, in respect of its space and resources, to function as it is intended ${ }^{1}$. The operational capacity of UK prisons refers to,

the total number of prisoners that an establishment can hold taking into account control, security and the proper operation of the planned regime. It is determined by the Deputy Director of Custody on the basis of operational judgement and experience. (Ministry of Justice (MoJ) 2016b: no page)

According to this description, UK prisons are able to fill their available space with a maximum number of prisoners, and that maximum capacity is not based on geometric space

\footnotetext{
${ }^{1}$ It should be noted that the function of prisons differs contextually, with some organised as space of punishment and retribution; others as spaces of reform and rehabilitation, or a combination of both.
} 
alone but also on the capacity of the prison to function as intended without control, security and the ability to carry out everyday regimes of activities (the 'function' of the prison) being compromised. There is much room for manoeuvre here, with this 'capacity' being determined on a case-for-case, prison-by-prison basis, centred on the 'judgement and experience' of the Deputy Director of Custody. Recently released figures from the Ministry of Justice (MoJ) reveal the 'operational capacity' of prisons in the United Kingdom from May 2016 (Table 2). Here it is possible to see where prison capacities exceed the recommended space allowances, but still enable the prison to function within its operational capacity. Unpicking these figures allows us to scrutinise how capacity is political; how available geometric space (and the rights of the prisoner) can be reduced, yet the capacity of the prison to function, remains 'uncompromised'.

$<$ Insert Table 2: Populations and capacities of selected prisons in England and Wales (from May 2016) (figures sourced from MoJ 2016a) about here>

The statistics in Table 2 reveal the maximum capacity of UK prisons in terms of the total volume of bodies (inmates) that each prison can hold. Yet the Certified Normal Accommodation rate $(\mathrm{CNA})^{2}$ refers to the total number of bodies (inmates) that should be held in each establishment. Figures then relate to the percentage of the CNA prison volume 'filled' by the population of prisoners. Therefore, according to the percentage of the population held within 'In Use CNA' most UK prisons are overcrowded; they are over

\footnotetext{
${ }^{2}$ Baseline Certified Normal Accommodation is the 'uncrowded' capacity of a prison. It is the 'good, decent standard of accommodation that the service aspires to provide to all prisoners' (MoJ, 2012: 11). The 'In Use CAN takes into account any cells not available for immediate use, such as those that are damaged or affected by building works.
} 
capacity. In other words, prisons contain more inmates than the establishment's CNA filling the prison more densely than originally planned.

Strikingly, although these prisons are technically deemed to be filled beyond a 'good, decent standard', most are still within their level of operational capacity ${ }^{3}$ - there is still space available to fill. The space available can be filled more densely. Considering the figures for the overall estate in England and Wales, although prisons are on average 111\% overcrowded, the total population is still 4000 prisoners less than the 'operational capacity'. In other words, in May 2016, there was room for 4000 more bodies within the penal system (MoJ 2016a). Relevant to our discussion, we note that these capacities provide 'guidance, rather than absolute limits' about maximum prison numbers (MoJ 2012: 11). Indeed, Baird and Rowlinson have, in their Measuring the Output of the Prison Service report, criticised measures such as CNA, which 'lacks transparency' as it based on 'professional judgment rather than volume of cell and facilities required for each individual' (Baird and Rowlinson 2009: 8). Here we see a tension where geometric measurements (such as CNA and ICRC recommendations) are designed to protect the rights of the inmate, but where conversely a 'judgement' call allows maximum capacities to be stretched, because the available space can be filled to a higher density. Interestingly, in the prison setting, where the populations have diminished rights, and where public perception is ever critical to prisoners having 'too much

\footnotetext{
${ }^{3}$ The figure for operational capacity is higher than the CNA and represents the maximum number of inmates a prison can hold, taking into account control, security and the proper operation of the planned regime of that establishment. In practice, this usually means placing bunk beds in cells originally designed for a single bed. Intriguingly, across the estate, the 'useable operational capacity' refers to the sum of all the establishment's operational capacities minus 2000 places. This ‘operating margin' reflects the ‘constraints imposed by the need to provide separate accommodation for different classes of prisoner. That is by sex, age, security category, conviction status, single cell risk assessment and also due to geographical distribution' (Baird and Rowlinson,
} 2009: 7). 
space' or 'too many privileges', geometric spatial calculations work to assist charitable organisations. They may argue for the basic rights of prisoners in contexts where those dimensions are - although used to design prison spaces - made malleable in operational terms as the mass of the prison can be increased by packing the volume of space more densely, dependent on each given operational situation.

Conversely, outside of a prison setting, in our cities, towns and villages, where 'operational capacities' for work, health care, benefits and so on could be stretched and made malleable to accommodate greater numbers or higher densities (see Martin and Secor 2015), geometric calculations have been solidified and borders hardened as part and parcel of political campaigns in an effort not to 'over-fill' a volume of space. Capacity then, is a political tool. In highlighting the space requirements of a prison cell and Certified Normal Accommodation levels we have here drawn attention to the paradoxical way that capacity is used and employed by different parties in respect of carceral space. Yet capacity can be understood not only in terms of the absolute versus operational 'amounts' a space might be filled. We can also unlock the politics of capacity in non-geometric ways - interrogating capacity as potential.

\section{Prison space II: 'Capacity building'}

The example of operational capacity illustrates how power works differently through volume (even where policy is 'flat') compared to the 'articulations' of power (Sharp et al. 2000: 3) described by Elden (2013), Graham (2004) and others (Bridge 2013; Gordillo 2015; Squire 2016; Steinberg and Peters 2015). Elden and others have demonstrated how power is not expressed across horizontal, planar surfaces (see Elden 2013: 49) but rather how power is projected through volumes of space. As Adey et al. have described in respect of aerial targeting from above, locating markers from the sky is not simply a linear process of 
identification from the top, down. Rather it is a process of 'cutting through the volumetric mediums of air, infrastructure, concrete and earth' (2011: 181). Yet, capacity allows us to unlock a different politics of volume. We have shown how power can be expressed by how much a volume might be filled; how densely it might be packed. In the case of the prison the mass of the population becomes a political matter for both charitable organisations and prison management, particularly in an age of punitiveness where the public demand harsher punishments, and welfare agencies demand better rights. The state is able to project power through volume through 'operational capacities' which are not based on maximum and minimum capacities but case-by-case judgement calls. These judgement calls, however, reveal another facet of capacity - that it is a potential, or a possibility. Capacity can be thought of as a mathematical calculation based on the 'maximum amount that can be held or contained' in a given space (Oxford English Dictionary (OED) 2017). Yet capacity takes on another meaning as potential or capability. The Oxford English Dictionary likewise describes capacity as the 'ability or power to do or understand something' (2017). In this respect, we may consider the capacity of prison for potential building for inmates; the capacity of staff to deal with day-to-day tasks and exceptional crises as their volume in numbers reduces; the capacity of opportunities for rehabilitation and change in work and education programmes for prisoners; and indeed, the capacity of policy to reduce levels of crime per se. This provides us with a non-Euclidean way of thinking of the politics of capacity; one where capacity is topologic - where a given capacity can be reshaped, moulded, reformed, stretched in different scenarios and spaces (see Martin and Secor 2015).

Indeed, in 2016 Liz Truss, the Secretary of State for Justice, issued a White Paper entitled: Prison Safety and Reform, which would, in part, focus on the capacity of staff to have an impact upon the spaces of incarceration that they work within, and the inmates that they work with. Only through providing staff with the power or capacity to care, mentor or 
educate could the capacity building of inmates themselves be realised. As studies have shown, prison officers and their particular work ethics can influence inmate behaviour and their motivation for reform (Nielsen 2011; Tait 2011). As Truss would contend in her White Paper,

[a]ll staff members working in our prisons and young offender institutions are agents of reform. Without their support and engagement, and the leadership of governors, we will not achieve our vision of making prisons work (MoJ 2016c: 12).

As a 'agent' with the capacity to 'reform', prison staff, the report noted, should not be 'just security guards and minders' but also 'mentors' (MoJ 2016: 3). Further, Truss announced that staff 'will have the resources, authority and tools need to break through the road blocks to reform and take on the challenge of transforming lives' (MoJ 2016c: 3, emphasis added). In these and other statements, the White Paper noted that appropriate training is essential for '[b]uilding the capability of our leaders' (MoJ 2016c: 53, emphasis added). In other words, prison staff must reach their own individual capacities before they can have an impact upon others.

Moreover, staff capacity building and training is intrinsic to many penal regimes across the world. Specifically, in Cameroon, workshops are aimed at 'building the capacity of prison officials on issues of Human Rights in order to contribute to the improvement of detention conditions and protect the rights of inmates' (Forestry, Agriculture, Animal and Fishery Network (FAAFNET) and International Centre for Environmental Education \& Community Development (ICENECDEV) 2013: n.p.). In a different register, The International Network to Promote the Rule of Law (INPROL) has recognised that 'prison staff capacity may be weak in postconflict countries (2017: n.p., emphasis added). In this 
case, an 'extreme shortage' of staff in postconflict countries such as Kosovo and East Timor, coupled with the recognition that existing staff require ongoing training, has resulted in 'targeted prison staff capacity building and training' in developing countries (INPROL 2017: n.p.) to improve the overall capacity of the prison to function as intended.

As can be gleaned from the attitude towards the purpose of staff in the prison service in the UK in particular, there is a clear recognition that prisoners also have 'the capacity for change' or can 'reach their capacity' particularly surrounding their ability to build opportunities for rehabilitation and release. From the academic literature, there has also emerged a line of inquiry into the paradoxical status of the prisoner, as both outside of the fabric of society, and aspirant for re-integration (Moran et al 2013; Turner 2013). For Rose (2000) incarceration is a mechanism used to detain members of society who detract from the ideals of society, even though these 'incorrigible individuals' are then supposed to conform to the concept of the responsible, modern citizen once imprisoned. Rehabilitation strategies are used to create this condition, and are a form of 'work experience' where the intent is to 'remoralise' and 'responsibilise' individuals such that they are able to work without benefit and further support (Rose 2000: 330).

We have noted in this paper how geometric, Euclidean ways of thinking spatially however unfashionable - are important to unpick because of their continued usage in politics and policy-making. Here we continue this line of thinking, in respect of theorisations of power (Sharp et al. 2000). Traditionally power has been understood as the 'capacity to act'; where power is projected from the top-down, from the 'powerful', to the powerless (see Panelli 2004). Whilst it is now acknowledged that 'there is no binary and all-encompassing opposition between rulers and ruled at the root of power relations' and that 'power is exercised from innumerable points' (Foucault 1981, 94, Cited in Holloway and Hubbard 2001 205), traditional discourses of power continue to pervade prison policy, where the 
mission of the prison, its programmes and its staff represent a way of thinking of about power as exercised from the top down, with staff having the ultimate capacity to act in order to evoke change. Such discourses (and practices) must be critiqued to expose more productive ways in which the capacities of prisoners may be realised, without them solely understood as resting on the capabilities of staff.

Indeed, there are efforts in prisons in the UK and globally where the incarcerated individual as a 'passive' subject is being challenged through the agency of the prisoner in shaping or building their own potential or capacities. Some examples of projects designed to help prisoners gain a sense of 'giving something back' through purposeful activity includes such things as the US 'Puppies behind Bars project' where prisoners raise guide dogs for the blind (Cheakalos 2004) or 'strengths-based' or 'restorative' activities with 'worthy causes' including repair of wheelchairs and community regeneration schemes (Burnett and Maruna 2006), and helping the elderly (Toch 2000). Turner $(2016,2017)$ explores the Koestler Awards as a mechanism through which prisoners are encouraged to produce art for potential scrutiny by both competition judges and members of the public visiting an exhibition of selected pieces. Here, prisoners engaging with artwork have managed to achieve a variety of successes. By offering artwork for sale, prisoners can contribute to a system of production and economic exchange that allows them to supplement their prison earning and reduce their reliance on informal welfare networks. Furthermore, both the accreditation and pleasure that prisoners have derived from producing artwork has allowed them to work on transforming themselves into more creative individuals. The properties associated with this are much valued in their potential to encourage individuals to aim for a prosperous future or to 'reach their capacities' both within, and outside of prison. 


\section{Towards a politics of capacity}

In recent years 'volume' has become an important analytic tool for making sense of powerrelations and the operation of geopolitics past and present, where power is understood as distributed, and resisted, through height, depth and angles (Elden 2013). Yet in this paper we have argued that we might extend our understandings of volume by thinking beyond 'volume' as three-dimensional space alone, to instead the qualities or characteristics that come to define volume. For mobilities scholars, movement has often been described as just that - movement. But as Cresswell argues (2010), movement takes on different forms and different characters through routes, speeds, experiences, forces and frictions. And further, as Peters has shown (2015) there is some mileage to breaking down mobilities into "constituent parts' (Cresswell 2010) and thinking about the politics encapsulated, created, shaped and reshaped by specific 'typologies' of motion from drifting to creeping, to flowing, to stalling. Here, we have followed this lead by showing how it might be useful to unpack and contemplate the politics of other descriptors of volume; notably capacity.

Capacity, most commonly and in ecological and demographic readings, describes the maximum volume of ' $\mathrm{X}$ ' that can be contained within a particular space. It is a geometric calculation of the extent to which given dimensions might be filled. It raises questions of density and mass. It is likely that geographers have shied away from thinking with capacity given such discussions rest upon Euclidean and geometric notions of space as a sealed container (Couclelis 2013), and the limits of population in respect of geometric measures of resources (Seidl and Tisdell 1999). Yet, as we have shown, although such thinking may be unfashionable in disciplinary terms, thinking through the lens of capacity is both timely and relevant, where the term is increasingly being utilised for political and policy work and where ' $\mathrm{X}$ ' is not just a number, but refers to people, who will experience such capacity. 
In geography we should be alerted to the continued usage of age-old, problematic spatial discourses which are put to work in contemporary socio-political discourses. It is our capacity as geographers to unveil and unpick the use of ideas and the implementation of actions in order critique a 'politics of capacity' (particularly where such capacities rest on flat spatial conceptualisation). Moreover, we have also shown how capacity as the "power or ability or act and understand' (OED 2017) also leads us back to conceptualisations of power as the 'capacity to act' (See Sharp et al. 2000); where too, we must challenge such manifestations of power as they arise in approaches to controlling, regulating and ultimately subjugating given populations.

In this paper we have drawn out our arguments by considering the politics of capacity in carceral settings, focusing on the 'operational capacities' and 'capacity building' related to prison regimes in the UK and overseas. Capacity in the prison setting need not only be related to the density or mass of bodies in space (as we have illustrated), but may also relate to resources and the politics related to their use. For example, volumetric measurements are noted regarding the recommendations made in respect of the water that prisoners should have access to, and the capacity or ability prisoners have to wash and to drink. The International Committee of the Red Cross (ICRC) recommends a minimum flow of 3-5 litres per minute of water to be provided for use in a prison. In terms of supply, 10-15 litres of water per day, per prisoner is considered to be minimum capacity to cover all needs. At the very least, 3-5 litres per person per day is required for survival and 1 litre per person per day for washing after using the toilet. Prisons should be able to store the total minimum consumption for one day and 2 litres per person should be available in each cell, room or dormitory for use at night (ICRC 2012: 31). These recommendations are based on those issued by WHO (World Health Organization) and those used for refugee camps (Davis and Lambert 1995: 201; UNHCR 1992). But just like other manifestations of working with capacity in the prison setting, 
realities depend on 'institutional and cultural settings' and on 'public perception' (see Seidl and Tisdell 1999). As such, there is further work to do for thinking of and with capacity in the prison setting. Yet, whilst carceral spaces - where questions of capacity are paramount provide useful case studies for thinking with volume differently, they also allow us to develop fresh theoretical advances for thinking spatially that might be applied more widely in geography per se.

\section{Epilogue}

On the 23rd June 2016, the United Kingdom entered a new phrase of its history through a referendum that was to decide its future in the collective institution of the European Union. In a result that caused jubilant celebration on one side, and deep devastation on the other, the UK voted by a narrow margin to leave the Union. During the days and weeks that preceded the vote, the campaign on both sides - 'Leave' and 'Remain' - orientated their arguments towards several key issues related to the economy, to resource provision, and notably, to levels of migration. Capacity - it would emerge - was the central battleground on which the vote was won and lost.

A controversial poster unveiled by Nigel Farage of the United Kingdom Independence Party (UKIP) depicted a stream of refugees queuing for a safe haven from their war-torn countries. Aside from much anger at the image (which exploited the very harsh realities refugees face, as well as conflating refugees with migrants, the latter of whom were the focus of sustained campaign debates), the poster revealed one of the key issues central to the referendum. Britain, the poster declared, was at 'Breaking Point' (Leave Campaign 2016). Britain was 'full'. The population was spilling over a threshold. Other central claims of the 'Leave' manifesto related also to capacity: the operational capacity of resources (a strained National Health Service (NHS)); an abused benefits system; a stretched housing provision) 
and the capacity of economy to cope with the demands of the supposedly 'unsustainable' growth of the population.

Although less explicit, capacity also emerged in the 'Remain' campaign as a fundamental device. On the day preceding the election, one frustrated pro-EU voter purchased a full-page newspaper spread in the London Metro which appeared empty, but for a simple pie diagram. This depicted the percentage of migrants entering the UK per year versus the UK's population as a whole. The figure of a mere $0.5 \%$ stood out in bold text, questioning the legitimacy over the UK's capacity for accepting migrants. As the voter declared 'Why can't we cope with a $0.5 \%$ yr rise in population?' (Morley 2016). The central tenet of the 'Remain' campaign was also focused on the 'capacity building' potential of staying within the EU. The EU, the then Prime Minister David Cameron repeatedly stated, would enable the UK to be more secure, more affluent, more diverse, more connected, more outward-looking. Capacity was not simply a physical, geometric calculation of available resources (space, services, finance), but a social ability and aptitude to act and live in a particular way.

Capacity, throughout the campaign, was not an apolitical matter of the (supposedly) available dimensions in which social life could be lived; or simply a question of capabilities and potentials. Capacity was political tool. Capacity became the means of heated discussion between politicians across Europe, within the United Kingdom, and even (as would be realised after the result) at the scale of individual families who disputed at the kitchen table whether the choice to leave was 'right' and 'wrong' (Wheeler 2016).

Stuart Elden has recently reminded us that 'volume matters' and 'volume opens up new ways to think' (Elden 2013: 49). In this paper we have argued that volume matters as capacity, and that capacity offers us a new way to think with volume. In short - capacity, we have demonstrated, does political work. From the scale of the prison, to nation-state politics, 
now, more than ever, it is important to critically analyse the political work of 'capacity' and use our capacity as geographers to further 'unlock the volume' to make sense of the spatial politics of the present.

\section{References}

Adey P (2010) Vertical security in the megacity legibility, mobility and aerial politics.

Theory Culture \& Society 27(6):51-67

Adey P, Whitehead M and Williams AJ (2011) Introduction: Air-target distance, reach and the politics of verticality. Theory Culture \& Society 28(7-8):173-187

Anderson B and McFarlane C (2011) Assemblage and geography. Area 43(2):124-127

Baird A and Rowlinson A (2009) UK Centre for the Measurement of Government Activity:

Measuring the Output of the Prison Service. London: Office for National Statistics

Bozovic M (ed) (1995) The Panopticon Writings. London: Verso

Bridge G (2013) Territory, now in 3D! Political Geography 34:55-57

Burnett R and Maruna S (2006) The kindness of prisoners. Criminology and Criminal Justice 6(1):83-106 
Carroll T (2010) The Great Escape from Stalag Luft III: The Full Story of How 76 Allied Officers Carried Out World War II's Most Remarkable Mass Escape. London: Simon and Schuster.

Cheakalos C (2004) New leash on life - in an innovative program, prison inmates find that raising puppies for the blind makes a difference. Smithsonian 35(5):62-68.

Couclelis H (2015) Space, time, geography. In PA Longley, MF Goodchild, DJ Maguire and DW Rhind (eds) Geographic Information Science and Systems (pp 29-38). London: Wiley

Community Action on Harm Reduction (CAHR) (2013) “Capacity Building for Prison Staff in Indonesia." http://www.cahrproject.org/news/capacity-building-training-for-prison-staff/ (last accessed 10 January 2017)

Conlon D (2011) Waiting: Feminist perspectives on the spacings/timings of migrant (im)mobility. Gender, Place and Culture 18(3):353-360

Council of Europe (2005) Commentary to Recommendation Rec (2005) of the Committee of Ministers to Member States on the European Prison Rules. Strasbourg: Council of Europe, Strasbourg

Cresswell T (2010) Towards a politics of mobility. Environment and planning D: Society and Space 28(1):17-31 
Crewe B (2014) Not looking hard enough: Masculinity, emotion and prison research Qualitative Inquiry 20(4):426-437

Davis J and Lambert R (1995) Engineering in Emergencies: A Practical Guide for Relief Workers. London: RedR

Elden S (2013) Secure the volume: Vertical geopolitics and the depth of power. Political Geography 34:35-51

Evershed N (2014) 'Drone used in attempt to smuggle drugs into Melbourne prison, say police' The Guardian. https://www.theguardian.com/world/2014/mar/10/drone-used-inattempt-to-smuggle-drugs-into-melbourne-prison-say-police (last accessed 5 February 2016)

Forestry, Agriculture, Animal and Fishery Network (FAAFNET) and International Centre for Environmental Education \& Community Development (ICENECDEV) (2013) Proceedings of the "Regional Workshop on Capacity Building for Penitentiary Staff on Human Rights and Improvement of Prison Conditions in Cameroon” Buea, 3-4 April 2013. http://www.icenecdev.org/PRISON-ADMINISTRATORS-WORKSHOP-REPORT.pdf (last accessed 10 January 2017)

Gill N (2009) Governmental mobility: The power effects of the movement of detained asylum seekers around Britain's detention estate. Political Geography 28:186-196

Gordillo GR (2014) Rubble: The Afterlife of Destruction. Durham NC: Duke University Press 
Graham S (2004) Vertical geopolitics: Baghdad and after. Antipode 36(1):12-23

Graham S (2011) Cities Under Siege: The New Military Urbanism. London: Verso

Graham S and Hewitt L (2013) Getting off the ground on the politics of urban verticality. Progress in Human Geography 37(1):72-92

Halliday S (2014) The Little Book of Crime and Punishment. The History Press: London

Holloway L and Hubbard P (2001) People and place: The Extraordinary Geographies of Everyday Life. Harlow: Pearson Education

International Committee of the Red Cross (ICRC) (2012) Water, Sanitation, Hygiene And Habitat In Prisons. Geneva: International Committee of the Red Cross

The International Network to Promote the Rule of Law (INPROL) (2017) Prison Staff Capacity Building and Training. http://inprol.org/rule-of-law-topics/prison-staff-capacitybuilding-and-training (last accessed 10 January 2017)

Latour B (2005) Reassembling the Social: An Introduction to Actor-Network-Theory. Oxford: Oxford University Press

Leave Campaign (n.d.) http://www.voteleavetakecontrol.org/ (last accessed 6 February 2017) 
Loyd JM, Mitchelson M and Burridge A (eds) (2013) Beyond Walls and Cages: Prisons, Borders, and Global Crisis. Athens, GA: University of Georgia Press

Marston SA., Jones JP and Woodward K (2005) Human geography without scale.

Transactions of the Institute of British Geographers 30(4):416-432

Martin LL and Mitchelson M (2009) Geographies of detention and imprisonment:

Interrogating spatial practices of confinement, discipline, law, and state power. Geography

Compass 3(1):459-477

Martin LL and Secor AJ (2014) Towards a post-mathematical topology. Progress in Human Geography 38(3):420-438

Massey D (2004) For Space Thousand Oaks, CA: SAGE

Milmo C (2010) "Daring Escape Foiled by Jail Staff Who Read between The Lines." http://www.independent.co.uk/news/uk/crime/daring-escape-foiled-by-jail-staff-who-readbetween-the-lines-2004769.html (last accessed 5 February 2016)

Ministry of Justice (2012) "Certified prisoner accommodation." https://www.justice.gov.uk/downloads/offenders/psipso/psi-2012/psi-17-2012-certifiedprisoner-accommodation.doc (last accessed 20 June 2016). 
Ministry of Justice (2016a) "Monthly Bulletin - May 2016."

https://www.gov.uk/government/statistics/prison-population-figures-2016 (last accessed 20 June 2016)

Ministry of Justice (2016b) "Population and Capacity Briefing for Friday 17th June 2016." https://www.gov.uk/government/statistics/prison-population-figures-2016 (last accessed 20 June 2016)

Ministry of Justice (2016c) "Prison Safety and Reform White Paper." https://www.gov.uk/government/uploads/system/uploads/attachment_data/file/565014/cm9350-prison-safety-and-reform-_web_.pdf (last accessed 10 January 2017)

Moran D (2012a) "Doing time" in carceral space: Timespace and carceral geography. Geografiska Annaler Series B-Human Geography 94B(4):305-316

Moran D (2012b) Prisoner reintegration and the stigma of prison time inscribed on the body. Punishment \& Society: International Journal of Penology 14(5):564-583

Moran D (2013) Between outside and inside? Prison visiting rooms as liminal carceral spaces. GeoJournal 78(2):339-351

Moran D (2015) Carceral Geography: Spaces and Practices of Incarceration. Farnham: Ashgate 
Moran D and Jewkes Y (2015) Linking the carceral and the punitive state: Researching prison architecture, design, technology and the lived experience of carceral space. Annales de Géographie 702-703:163-184

Moran D, Gill N and Conlon D (eds) (2013) Carceral Spaces: Mobility and Agency in Imprisonment and Migrant Detention. Farnham: Ashgate

Moran D, Turner J and Jewkes Y. (2016a) Becoming big things: Building events and the architectural geographies of incarceration in England and Wales. Transactions of the Institute of British Geographers 41(4):416-428

Moran D, Jewkes Y and Turner J (2016b) Prison architecture and carceral space. In Y Jewkes, B Crewe and J Bennett (eds) Handbook on Prisons (pp 114-130). Abingdon: Routledge

Moran D, Turner J and Schliehe A K (2017) Conceptualizing the carceral in carceral geography. Progress in Human Geography. Early Online. DOI: 0309132517710352.

Morley N (2016) "Who is Laurence Taylor? Guy with EU Referendum Ad in Metro Explains Why He Did It.” http://metro.co.uk/2016/06/22/who-is-laurence-taylor-guy-with-eureferendum-ad-in-metro-explains-why-he-did-it-5959925/\#ixzz4XtxLSpap (last accessed 27 July 2016)

Mountz A (2011) The enforcement archipelago: Detention, haunting, and asylum on islands. Political Geography 30(3):118-128 
Nielsen MM (2011) On humour in prison. European Journal of Criminology 8(6):500-514

Murdoch J (1998) The spaces of actor-network theory. Geoforum 29(4):357-374

Peters K (2015) Drifting: Towards mobilities at sea. Transactions of the Institute of British Geographers 40(2):262-272

Peters K, Steinberg P and Stratford E (forthcoming) Territory beyond Terra. London:

Rowman and Littlefield

Peters K and Turner J (2015) Between crime and colony: Interrogating (im)mobilities aboard the convict ship. Social and Cultural Geography 16(7):844-862

Pickering S (2014) Floating carceral spaces: Border enforcement and gender on the high seas. Punishment \& Society 16(2):187-205

Pickering S and Weber L (eds) (2006) Borders, Mobility and Technologies of Control. Netherlands: Springer

Price D (1999) Carrying capacity reconsidered. Population and Environment: A Journal of Interdisciplinary Studies 21(1):5-26

Rose N (2000) Government and control. British Journal of Criminology 40:321-329 
Sayre N F (2008) The genesis, history and limits of carrying capacity. Annals of the Association of American Geographers 98(1):120-134

Seidl I and Tisdell C A (1999) Carrying capacity reconsidered: from Malthus' population theory to cultural carrying capacity. Ecological Economics 31: 395-408

Sharp J, Routledge P, Philo C and Paddison R (eds) (2000) Entanglements of Power: Geographies of Domination/Resistance. London and New York: Routledge

Sloterdijk P (2009). Airquakes. Environment and Planning D: Society and Space 27(1):4157

Sloterdijk P (2011) Bubbles. Spheres Volume I: Microspherology. Cambridge MA: MIT Press

Sloterdijk P (2014) Globes. Spheres Volume II: Macrospherology. Cambridge MA: MIT Press

Sloterdijk P (2016) Foam. Spheres Volume III: Plural Spherology. Cambridge MA: MIT Press

Squire R (2016) Rock, water, air and fire: Foregrounding the elements in the Gibraltar-Spain dispute. Environment and Planning D: Society and Space 34(3):545-563 
Steinberg P and Peters K (2015) Wet ontologies, fluid spaces: Giving depth to volume through oceanic thinking. Environment and Planning D: Society and Space 33(2):247-264

Tait S (2011) A typology of prison officer approaches to care. European Journal of Criminology 8(6):440-454

Toch H (2000) Altruistic activity as correctional treatment. International Journal of Offender Therapy and Comparative Criminology 44(3):270-278

Turner J (2013) Re-‘homing' the ex-offender: Constructing a 'prisoner dyspora'. Area 45(4):485-492

Turner J (2016) The Prison Boundary: Between Society and Carceral Space. London: Palgrave Macmillan

Turner J (2017) The artistic 'touch': Engaging with the confined at the Art by Offenders exhibition. In D Moran and A Schliehe (eds) Carceral Spatiality: Dialogues between Geography and Criminology (pp 135-168). London: Palgrave Macmillan UNHCR (1992) Programme and Technical Support Section, Water Manual for Refugee Situations. UNHCR: Geneva

van Zyl Smit D and Snacken S (2009) Principles of European Prison Law and Policy. Oxford: Oxford University Press 
Walmsley R (1997) Prison Populations in Europe and North America. HEUNI Paper No. 10.

Helsinki: The European Institute for Crime Prevention and Control, affiliated with the United Nations (HEUNI)

Weizman E (2003) “The Politics of Verticality.” http://www.opendemocracy.net/ecologypoliticsverticality/article_801.jsp (last accessed 13 June 2014)

Wener R (2012) The Environmental Psychology of Prisons and Jails: Creating Humane Spaces in Secure Settings.Cambridge, MA: Cambridge University Press

Wheeler, B. (2016) “A Survival Guide For Families Split Over EU Referendum.” http://www.bbc.co.uk/news/uk-politics-35709755 (last accessed 6 February 2017) 